\title{
Functional disability and associated factors in elderly stroke survivors in Vitória, Brazil
}

\section{Abstract}

Objective: The aim of the present study was to estimate the prevalence of disability and associated factors in elderly stroke survivors. Methods: A cross-sectional study of 230 elderly persons was conducted in the 22 territories of the Estratégia de Saúde da Família (the Family Health Strategy) of Vitória, in the state of Espirito Santo. Patients were assessed using the modified Rankin Scale. Poisson regression with robust variance in crude and adjusted analyses was employed. Results: The majority of subjects were men (52.1\%) aged between 60 to 98 years, with a mean age of 75.8 ( $\mathrm{sd} \pm 9.2)$. The prevalence of disability was $66 \%$. Age $\geq 80$ years, self-perceived limitations in bodily function, considering the physical structure of the street to be a barrier to leaving home and believing street lighting to be insufficient were positively associated with functional disability. Possessing 12 or more years of schooling was inversely associated with the outcome. Conclusions: The high prevalence of disability and associated factors in elderly stroke survivors reinforce the need for a health system that operates continuously and proactively, promoting active aging.
Júlia Fabres do Carmo Elizabete Regina Araújo Oliveira ${ }^{2}$ Renato Lirio Morelato ${ }^{3}$
Keywords: Elderly. Stroke. Family Health Strategy. Aging. Primary Health Care. Public Health.

Prefeitura Municipal de Vitória, Departamento, Secretaria Municipal de Saúde. Vitória, ES, Brasil.

2 Universidade Federal do Espírito Santo, Departamento de Enfermagem e Saúde Coletiva. Vitória, ES, Brasil.

3 Escola Superior de Ciências da Santa Casa de Misericórdia de Vitória, Departamento de Clínica Médica. Vitória, ES, Brasil. 


\section{INTRODUCTION}

Population aging is considered a common phenomenon around the world. ${ }^{1}$ Proportionally, however, the increase in the elderly population and the decrease in the younger population is not the same in each country. While population aging is gradual in developed countries it is more accelerated in developing countries, and takes place before the desired economic development. ${ }^{2}$ In Brazil, the proportion of people aged 60 or more increased from $9.7 \%$ in 2004 to $13.7 \%$ in 2014. The Instituto Brasileiro de Geografia e Estatística (the Brazilian Institute of Geography and Statistics - IBGE) indicates that this trend will continue, with the ratio reaching $33.7 \%$ by 2060 , or in other words, when one in every three people will be 60 years or older. ${ }^{3}$

The growth of the elderly population is at the root of many of the challenges for health systems, because as time progresses the functional capacity of the individual declines and the risk of developing chronic diseases increases. ${ }^{2,4}$ Functional capacity can be defined as the set of physical and mental abilities needed to independently perform activities of daily living. Similarly, functional disability can be defined as the difficulty or inability to perform these activities. $^{5}$

From a broader perspective, the World Health Organization (WHO) defines disability as the product of a complex and dynamic interaction between health condition (such as injury and illness), personal factors (such as lifestyle, age and educational level) and environmental factors. ${ }^{6}$ The Politica Nacional de Saúde da Pessoa Idosa (the National Health Policy for the Elderly - PNSPI) ${ }^{7}$ argues that functional capacity is a new paradigm of health and that the main problem that affects the elderly today is not a specific disease, but the loss of functional capacity. Studies have shown that the rate of disability in the elderly population is between $19.2 \%$ and $26.8 \%{ }^{8,9}$

Considered to be the main cause of long term disability in adulthood, cerebrovascular accidents or strokes $(\mathrm{CVA})^{10,11}$ occupy a prominent position among the chronic diseases that affect the elderly population. ${ }^{2}$ According to the national system of hospital information, strokes are the main reason for hospitalization in the Sistema Único de Saúde (the Unified Health System - SUS). ${ }^{12}$ It is estimated that $25 \%$ to $74 \%$ of the 50 million stroke survivors in the world have some kind of disability, whether physical, emotional or cognitive, requiring partial or total assistance to perform activities of daily living. ${ }^{11}$ Brazilian surveys have revealed a strong association between strokes and disability $(\mathrm{OR}=51.8, p=0.05 ; \mathrm{OR}=6.62, p<0.001)$ of the elderly population. ${ }^{13,14}$

Population aging, the emergence of chronic diseases and long-term disabilities are challenges to contemporary public health and require changes to the health care model..$^{15}$ The PNSPI recommends that assessment and functional diagnostics are performed mainly in Primary Health Care (PHC) through the Family Health Strategy (FHS), to ensure the maximum autonomy of the elderly. Thus, calculating the prevalence of disability and identifying associated factors in elderly persons after strokes, within PHC, may contribute to the planning of strategies directed at the health needs of this population. Given this context, the present study aimed to assess functional disability and possible associated factors in older adults after CVAs, who were registered with the Family Health Strategy in the city of Vitória, Espirito Santo.

\section{METHOD}

A descriptive cross-sectional study was carried out in Vitória, the capital of the state of Espirito Santo. The municipality began the implementation of the Family Health Strategy in 1998 and currently has 29 Basic Health Units (BHUs), 22 of which are included in the FHS. ${ }^{16,17}$ The estimated population for the municipality in 2010 was 327,801 inhabitants and the number of people aged 60 or more registered in the 22 territories of the FHS totaled 29,552. ${ }^{16}$

Considering the population of registered elderly persons and the prevalence of strokes $(2.9 \%)^{18}$ the study population was calculated at 900 individuals. Subsequently, the prevalence of disability after a stroke was defined as $60 \%,{ }^{11,19}$ along with a significance level of $5 \%$, a margin of error of $7 \%$ 
and a design effect of 1.4, arriving at a minimum sample size of 218 elderly persons. To compensate for possible losses or refusals a further $5 \%$ was added, resulting in a sample of 230 subjects.

Sampling by quotas was carried out proportional to the number of elderly persons enrolled in each health territory. The number of elements to be observed in each of the 22 dimensions was defined by the formula: $\mathrm{n}^{1}=\mathrm{fxN}^{1}$, wherein:

$\mathrm{N}^{1}=$ total elements of the territory; $\mathrm{n}^{1}=$ size of sample in each territory; $\mathrm{f}=\mathrm{n} / \mathrm{N}$ ( $\mathrm{n}=$ sample size $\mathrm{N}=$ population size)

To operationalize selection, a strategy was designed with the FHS teams and technicians of the Municipal Health Department, which allowed access to the Rede Bem Estar (Wellness Network) (RBE), the health management software of the municipality. Through this system it was possible to identify elderly patients who had been clinically diagnosed as having suffered a CVA. When the number of elderly persons was not sufficient to reach the quota for the territory or in cases of death or a change of address the teams selected the remaining elderly persons required to complete the quota.

The inclusion criteria were: aged equal to or older than 60 years, had suffered a stroke and resided in a Family Health Strategy territory. Elderly persons who were not located after three attempts were excluded, as well as those who were not able to respond alone or who were not accompanied by a caregiver who was able to answer and those living in micro areas without a Community Health Agent (CHA).

Data was collected between October 2013 and May 2014. The interviews took place at the homes of participants and were accompanied by a CHA to facilitate access to homes and contact with the elderly. A team of three interviewers were trained and supervised by the researcher. A structured questionnaire with closed precoded questions was created for the study, which consisted of demographic data (gender, skin color, age, family income, level of education and living with a partner); health conditions (recurrence of stroke, presence of pain, diabetes, hospitalization in the last year, perception of health and difficulty in the following body functions: movement of the arms and legs, voice and speech, memory, chewing and swallowing, vision and sphincter control (urinary and fecal), as well as data on perception of the environment (has difficulty accessing health services, has difficulty leaving home because of architectural barriers, and whether signage on roads and walkways is sufficient/insufficient).

The outcome variable was measured by the modified Rankin Scale (mRS), which was chosen as it is the most commonly used instrument for measuring disability in contemporary research on CVAs. ${ }^{20}$ The scale consists of six categories ranging from 0 to 5 , with 0 corresponding to the absence of symptoms and 5 corresponding to severe disability. Following the trend of studies by Hardie et al. ${ }^{21}$ and Bettger et al. ${ }^{22}$ the turning point between functional capacity and disability was level 3 of the scale; thus those with $m R S \leq 2$ were classified as independent and those with $\mathrm{mRS} \geq 3$ were classified as functionally disabled.

Data was entered in Excel. Statistical analyzes were performed using the Statistical Package for Social Sciences software package (SPSS) version 22.0 for Windows. Initially, descriptive statistics were used for the outcome prevalence and the absolute and relative frequencies of the independent variables. Poisson regression with robust variance estimation was employed, with calculations of the unadjusted and adjusted prevalence ratio and a confidence interval of $95 \%$. For data analysis a hierarchical model was used that considered three levels to determine disability: the first level (distal) was perception of the environment variables, the second level (intermediate) was sociodemographic variables, and the third level (proximal) was variables related to health conditions. Multivariate analysis retained variables with a $\mathrm{p}$ value $<0.20$, considering the effect of the variable in relation to the outcome, controlled for the other variables of the same and higher levels. Variables with $\mathrm{p}<0.05$ were considered significant.

This study was approved by the Municipal Health Secretary of Vitória and the Ethics and Research Committee of the Santa Casa de 
Misericórdia de Vitória Science College, under CAAE number 14435213.6.0000.5065. All of the participants were fully informed about the nature of the study and signed a Free and Informed Consent Form.

\section{RESULT}

A total of 230 elderly persons aged between 60 and 98 years took part in the study. The mean age was 75.8 years $(\mathrm{SD}=9.2), 26.0 \%$ of the elderly individuals were aged between 60-69 years, $36.9 \% 70-79$ years and $36 ; 9 \% 80$ years or older. Individuals with between one and four years of schooling predominated (44.7\%), as well as those who described themselves as Non-white (55.8\%) and who had a family income of between one and three minimum salaries (40.3\%).

Just over half of the elderly persons were male (52.1\%) and lived without a partner (51.1\%).

Table 1. Description of sample. unadjusted and adjusted analysis of Functional Disability according to socioeconomic and demographic variables. Vitória. Espírito Santo. 2013/2014.

\begin{tabular}{|c|c|c|c|c|c|c|}
\hline Variables & $\mathrm{N}(\%)$ & $\begin{array}{l}\text { Disability } \\
(\%)\end{array}$ & $\begin{array}{c}\text { Unadjusted PR } \\
\quad(\text { CI } 95 \%)\end{array}$ & $\mathrm{p}$ & $\begin{array}{l}\text { Adjusted PR } \\
\text { (CI 95\%) }\end{array}$ & $\mathrm{p}$ \\
\hline \multicolumn{7}{|c|}{ Socioeconomic and demographic variables (intermediate level) } \\
\hline \multicolumn{7}{|l|}{ Gender } \\
\hline Male & $120(52.1)$ & 31.7 & 1 & & 1 & \\
\hline Female & $110(47.8)$ & 34.3 & $1.18(0.98-1.42)$ & 0.07 & $1.18(0.93-1.51)$ & 0.16 \\
\hline \multicolumn{7}{|l|}{ Age range } \\
\hline $60-69$ years & $60(26)$ & 14.7 & 1 & & 1 & \\
\hline $70-79$ years & $85(37)$ & 21.7 & $1.03(0.78-1.37)$ & 0.79 & $1.04(0.73-1.49)$ & \\
\hline$\geq 80$ years & $85(37)$ & 29.5 & $1.42(1.10-1.80)$ & 0.01 & $1.47(1.08-2.01)$ & 0.01 \\
\hline \multicolumn{7}{|l|}{ Skin color } \\
\hline Non-white & $128(55.8)$ & 54.3 & 1 & & 1 & \\
\hline White & $102(44.5)$ & 45.7 & $1.04(0.87-1.26)$ & 0.63 & $1.03(0.85-1.27)$ & 0.7 \\
\hline \multicolumn{7}{|l|}{ Family income } \\
\hline$<1$ min wage & $52(23.3)$ & 14.7 & 1 & & 1 & \\
\hline $1-3$ min wages & $90(40.4)$ & 27.3 & $1.04(0.89-1.22)$ & 0.60 & $1.06(0.88-1.26)$ & 0.49 \\
\hline 3-5 min wages & $49(22.0)$ & 14.3 & $1.02(0.84-1.22)$ & 0.83 & $0.99(0.80-1.23)$ & 0.99 \\
\hline$>5$ min wages & $32(14.3)$ & 7.3 & $0.87(0.71-1.09)$ & 0.26 & $0.79(0.64-1.02)$ & 0.08 \\
\hline \multicolumn{7}{|l|}{ Schooling } \\
\hline None & $48(21)$ & 17.3 & 1 & & 1 & \\
\hline 1 to 4 years & $102(44.7)$ & 28.6 & $0.77(0.64-0.94)$ & 0.009 & $0.73(0.57-0.94)$ & 0.01 \\
\hline 5 to 8 years & 27(11.8) & 6.9 & $0.71(0.50-0.99)$ & 0.04 & $0.62(0.39-0.98)$ & 0.04 \\
\hline 9 to 11 years & $33(14.4)$ & 9.1 & $0.76(0.57-1.01)$ & 0.06 & $0.67(0.45-1.01)$ & 0.60 \\
\hline 12 or more & $18(7.8)$ & 3.0 & $0.46(0.25-0.84)$ & 0.01 & $0.39(0.18-0.82)$ & 0.01 \\
\hline \multicolumn{7}{|l|}{ Lives with partner } \\
\hline No & $117(51)$ & 36.9 & 1 & & 1 & \\
\hline Yes & $112(48.9)$ & 29.1 & $0.83(0.68-1.00)$ & 0.06 & $0.79(0.61-1.50)$ & 0.07 \\
\hline
\end{tabular}

PR: prevalence ratio; CI: confidence interval of $95 \%$; statistically significant value $p \leq 0.05$. Minimum salary 2013: R $\$ 678.00$. 
Many of the respondents $(43.9 \%)$ had suffered more than one CVA. Regarding selfperceived health, $54.5 \%$ considered their health as good or very good. $36.0 \%$ said they had been diagnosed with diabetes and 56.5\% experienced musculoskeletal pain. Just over a third $(36.9 \%)$ had been hospitalized in the previous year. When asked about the limitations that arose after a CVA, more than half reported having difficulty with between three and five body functions (56.5\%), with the most cited difficulty with moving legs $(84.3 \%)$, arms $(74.7 \%)$ and difficulty with memory (51.3\%).

Table 2. Description of sample, unadjusted and adjusted Functional Disability according to health condition variables. Vitória, Espírito Santo. 2013/2014.

\begin{tabular}{|c|c|c|c|c|c|c|}
\hline Variables & $\mathrm{N}(\%)$ & $\begin{array}{c}\text { Disability } \\
(\%)\end{array}$ & $\begin{array}{c}\text { Unadjusted } \\
\text { PR } \\
(\mathrm{CI} 95 \%)\end{array}$ & $\mathrm{p}$ & $\begin{array}{l}\text { Adjusted PR } \\
\text { (CI 95\%) }\end{array}$ & $\mathrm{p}$ \\
\hline \multicolumn{7}{|c|}{ Health condition variables (proximal level) } \\
\hline \multicolumn{7}{|l|}{ More than $1 \mathrm{CVA}$} \\
\hline No & $129(56.0)$ & 33.9 & 1 & & 1 & \\
\hline Yes & 101(43.9) & 32.1 & $1.21(1.01-1.45)$ & 0.03 & $1.26(0.99-1.60)$ & 0.06 \\
\hline \multicolumn{7}{|l|}{ Pain } \\
\hline No & $100(43.5)$ & 26.0 & 1 & & 1 & \\
\hline Yes & $130(56.5)$ & 40.0 & $0.84(0.69-1.03)$ & 0.09 & $1.19(0.93-1.53)$ & 0.16 \\
\hline \multicolumn{7}{|l|}{ Diabetes } \\
\hline No & $147(63.9)$ & 40.0 & 1 & & 1 & \\
\hline Yes & $83(36.0)$ & 26.0 & $1.15(0.96-1.38)$ & 0.12 & $1.16(0.91-1.48)$ & 0.21 \\
\hline \multicolumn{7}{|l|}{ Self-perceived health } \\
\hline Good & $101(54.5)$ & 23.0 & 1 & & 1 & \\
\hline Poor & $84(45.4)$ & 23.9 & $1.24(0.98-1.58)$ & 0.07 & $1.23(0.97-1.57)$ & 0.08 \\
\hline \multicolumn{7}{|c|}{ Hospitalization in previous year } \\
\hline No & $145(63.0)$ & 38.6 & 1 & & 1 & \\
\hline Yes & $85(36.9)$ & 27.4 & $1.20(1.01-1.44)$ & 0.04 & $1.25(0.98-1.58)$ & 0.06 \\
\hline \multicolumn{7}{|l|}{ BF Limitations } \\
\hline $0-2$ & $52(22.6)$ & 9.1 & 1 & & 1 & \\
\hline $3-5$ & 132(57.9) & 39.1 & $1.65(1.16-2.34)$ & 0.005 & $1.57(1.09-2.28)$ & 0.010 .01 \\
\hline$\geq 6$ & 47 (20.4) & 17.8 & $2.16(1.53-3.05)$ & 0.001 & $2.00(1.33-2.99)$ & \\
\hline
\end{tabular}

PR: prevalence ratio; CI: confidence interval of $95 \%$; statistically significant value $p \leq 0.05$. BF: Body Function

As regards perception of environment, $54.7 \%$ said that the signage of pedestrian walkways and footbridges was insufficient, $58.2 \%$ found it difficult to leave due to architectural barriers and $40.4 \%$ described experiencing difficulty in accessing health services (Table 3). The prevalence of disability in the studied population was $66 \%$ $(\mathrm{mRS} \geq 3)$. Table 4 shows the sample distribution by the Rankin scale classification. 
Table 3. Description of sample, unadjusted and adjusted analysis of Functional Disability according to perception of built environment variables. Vitória, Espirito Santo, 2013/2014.

\begin{tabular}{|c|c|c|c|c|c|c|}
\hline Variables & $\mathrm{N}(\%)$ & $\begin{array}{l}\text { Disability } \\
(\%)\end{array}$ & $\begin{array}{l}\text { Unadjusted PR } \\
\text { (CI 95\%) }\end{array}$ & $\mathrm{P}$ & $\begin{array}{l}\text { Adjusted PR } \\
\text { (CI 95\%) }\end{array}$ & $\mathrm{p}$ \\
\hline \multicolumn{7}{|c|}{ Environmental Perception Variables (distal level) } \\
\hline \multicolumn{7}{|c|}{$\begin{array}{l}\text { Difficulty in leaving } \\
\text { the house due to } A B\end{array}$} \\
\hline No & $96(41.7)$ & 20.8 & 1 & & 1 & \\
\hline Yes & $134(58.2)$ & 45.2 & $1.55(1.24-1.93)$ & $<0.001$ & $1.89(1.39-2.57)$ & $<0.001$ \\
\hline \multicolumn{7}{|l|}{ Road signage } \\
\hline Sufficient & $103(44.7)$ & 26.0 & 1 & & 1 & \\
\hline Insufficient & $126(54.7)$ & 39.5 & $1.32(1.01-1.50)$ & 0.03 & $1.32(1.02-1.71)$ & 0.03 \\
\hline \multicolumn{7}{|c|}{ Difficulty accessing } \\
\hline No & $137(59.5)$ & 37.3 & 1 & & 1 & \\
\hline Yes & $93(40.4)$ & 28.6 & $1.13(0.94-1.35)$ & 0.18 & $1.22(0.96-1.55)$ & 0.10 \\
\hline
\end{tabular}

PR: prevalence ratio; CI: confidence interval of $95 \%$; statistically significant value $p \leq 0.05$; AB: Architectural Barrier, HS: Health Service.

Table 4. Distribution of sample according to degree of disability according to modified Rankin Scale. Vitória, Espirito Santo, 2013/2014.

\begin{tabular}{|c|c|c|c|c|}
\hline Degree & Rankin Scale Classification & Description & $\mathrm{n}$ & $\%$ \\
\hline 1 & No significant disability & $\begin{array}{l}\text { Capable of carrying out normal tasks and } \\
\text { activities. }\end{array}$ & 37 & 16.1 \\
\hline \multirow[t]{2}{*}{2} & \multirow[t]{2}{*}{ Mild disability } & \multirow[t]{2}{*}{$\begin{array}{l}\text { Incapable of carrying out previous activities. but } \\
\text { independent of personal care. }\end{array}$} & & \\
\hline & & & 41 & 17.8 \\
\hline 3 & Moderate disability & $\begin{array}{l}\text { Requires some assistance. but is capable of } \\
\text { walking without assistance (can use cane or } \\
\text { walker). }\end{array}$ & 67 & 29.1 \\
\hline 4 & Moderate/severe disability & $\begin{array}{l}\text { Incapable of walking without assistance and } \\
\text { meeting own physiological needs without help. }\end{array}$ & 36 & 15.7 \\
\hline 5 & Serious disability & $\begin{array}{l}\text { Bed-ridden. Incontinent. Requires care and } \\
\text { constant nursing attention. }\end{array}$ & 49 & 21.3 \\
\hline
\end{tabular}


In unadjusted analysis the variables 80 years or older, 12 or more years of study, experience problems with three or more body functions, have suffered more than one CVA, have been hospitalized in the last year, report difficulty leaving the house because of architectural barriers and consider road and walkway signage to be insufficient were associated with the outcome (Table 1, 2 and 3).

In adjusted analysis the prevalence of disability was significantly higher among elderly patients aged 80 years or older than among those aged 60 69 years (PR=1.47, CI 95\% 1.08 to 2.01). Elderly persons with 12 years or more of schooling had a lower prevalence of disability than individuals with no education ( $\mathrm{PR}=0.39$; $\mathrm{CI} 95 \% 0.18$ to 0.82 ), (Table 1). Those who perceived problems in six or more body functions were twice as incapacitated as those who perceived limitations in zero to two body functions (PR 2.00, CI 95\% 1.33 to 2.99) (Table 2).

Among the distal level variables, there was a significant association between disability and difficulty in leaving home because of architectural barriers ( $\mathrm{PR}=1.89$; CI 95\% 1.39 to 2.57) and considering the signage of roads and walkways to be insufficient ( $\mathrm{PR}=1.32 ; 1.02$ to 1.71 ), (Table 3). Having suffered more than one stroke and hospitalization in previous year lost significance after adjustment for the other variables.

\section{DISCUSSION}

In the present study, the prevalence of disability among elderly persons after a CVA was $66 \% .{ }^{23}$ A household-based survey carried out in France found that $34.5 \%$ of the population suffered functional disability (mrs $\geq 3$ ) after a CVA, or in other words one in every three stroke survivors was in a position of dependency. ${ }^{23}$ In a similar survey in Brazil the prevalence of disability was $29.5 \%$ in men and $21.5 \%$ in women. ${ }^{24}$ Neither study delimited age and the Brazilian study did not apply an instrument to assess functional capacity.
Half of CVA survivors in a Brazilian rehabilitation center exhibited functional disability ( $\mathrm{mRS} \geq 3$ ), while $23.5 \%$ were classified with moderate dependence and $29.3 \%$ with severe dependence (mRS $=4) .{ }^{25} \mathrm{~A}$ multi-center study conducted in Pakistan found that $64 \%$ of the population who had suffered a CVA was functionally disabled (mRS $\geq 3) .{ }^{26}$ Chandra et al. ${ }^{19}$ divided the population after a CVA into two groups: under 80 and 80 or older, and found that $74 \%$ of elderly people were functionally disabled ( $\mathrm{mRS} \geq 3$ ).

Kisoli et al. ${ }^{27}$ assessed disability among an elderly population with various neurological diseases using the Barthel Index and found that $63 \%$ of CVA survivors were dependent for basic activities of daily living. It can be seen that there is a large discrepancy in the prevalence of disability and many factors can influence such rates, such as the sample location, age of participants, the recurrence of CVAs, the time of evaluation and the type of instrument applied. ${ }^{28}$

The present study found a higher prevalence of disability among elderly persons aged 80 or more, a result in line with national and international studies, which found that advancing age was associated with functional loss in the elderly population. . $^{814,29}$ Studies evaluating CVA survivors also associated old age with disability. ${ }^{19,25}$ There is a consensus in literature that functional capacity increases during childhood, reaches its peak in early adulthood and declines soon after, although the speed of such decline is not the same for everyone and is determined by factors related to lifestyle and environmental and external factors. ${ }^{2}$

Elderly persons who reported problems with or the loss of six or more body functions showed a higher probability of suffering disability than those who described problems in none or up to two functions. The World Health Organization ${ }^{6}$ through the International Classification of Functioning, Disability and Health defines disability as a problem in the functions or structures of the body, and therefore this result demonstrates a connection between the perception of disability and incapacity measured by the Rankin Scale. 
There was a significant association between living with disabilities and considering that the physical conditions of the street made it difficult to leave home and that roads and walkways were lacking signage. Lien et al. ${ }^{30}$ associated the perception of environmental physical barriers with disability in basic and instrumental activities of daily living among elderly Thai people. Zhang et al. ${ }^{31}$, assessing CVA survivors in rural China, found an association between physical barriers and limitations in performing activities and restrictions in participation. The WHO says that environmental characteristics influence the functional capacity of individuals and many people could achieve a higher level of functionality if they lived in more favorable environments. It recommends, among other things, the removal of barriers, the creation of safe neighborhoods, the establishing of standards and guarantee of accessibility in buildings, houses and modes of transport. ${ }^{32}$

The present study identified an inverse association between education and disability. This result corroborates Brazilian surveys that assessed the functional capacity of the elderly and concluded that a higher education makes disability less likely. ${ }^{13,28}$ The Pesquisa Nacional de Saude (National Health Survey) (PNS) associated a higher prevalence of CVAs with a lower educational level, but found no association between disability and the level of formal education among those who survived CVAs. ${ }^{24}$ In the last decade, according to IBGE data, there was a reduction in the illiteracy rate among all age groups except for the population aged over 65 years. Thus, the relative weight of the elderly in the illiterate population grew from $46.7 \%$ in 2004 to $58.2 \%$ in $2014 .^{3}$

By analyzing these results, it was observed that the association between suffering more than one CVA and experiencing disabilities lost significance after adjustment for other variables. Gall et al. ${ }^{33}$ found a positive association between suffering more than a stroke and having a disability. Park and Ovbiagele ${ }^{34}$ however, found a higher level of disability after a first CVA with the risk of recurrence.
Unadjusted analysis also identified a positive association between having been hospitalized in the last 12 months and having a disability, but this result was not maintained after adjusted analysis. Alves et al. ${ }^{29}$ found that elderly patients hospitalized in the previous year were highly likely to have great difficulty or a complete inability to climb a slope when compared to older people who had not been hospitalized.

Data was collected from 22 FHS territories in order to achieve a heterogeneous sample, representative of the elderly population of the city of Vitória. This can be considered a differential of this study when compared to similar studies conducted in rehabilitation centers and hospitals. On the other hand, limitations in the sample selection should be considered, such as the selection of subjects based on the information of health teams, a form of selection that is subject to diagnostic suspicion and information bias. In addition, cross-sectional studies are not analytical research strategies and their results do not establish causal links.

\section{CONCLUSION}

The present study revealed a high prevalence of disability among elderly persons who had suffered a CVA and were registered with the Family Health Strategy in Vitória, Espirito Santo. Many of the individuals with disabilities had experienced more than one CVA. The result reiterates the importance of applying measures to monitor functional capacity and the promotion of support for the elderly after CVAs within the Primary Healthcare System.

The Poisson regression model helped positively identify some factors associated with disability, such as: age, self-perceived limitations in body functions, considering the physical structure of the street as a barrier and road signage to be insufficient. A total of 12 years or more of schooling was inversely associated with functional disability, however. These findings may contribute to planning actions aimed at minimizing or delaying disability in the elderly after a CVA, as well as subsidizing public policies directed at the elderly. 


\section{REFERENCES}

1. Camarano AA, Kanso S, Fernandes D.

Envelhecimento populacional, perda da capacidade laborativa e políticas públicas brasileiras entre $1992 \mathrm{e}$ 2011. Rio de Janeiro: IPEA; 2013.

2. Organização Pan-Americana da Saúde. Envelhecimento ativo: uma política de saúde. Brasília, DF: OPAS; 2005.

3. Instituto Brasileiro de Geografia e Estatística. Síntese de indicadores sociais: uma análise das condições de vida da população brasileira. Rio de Janeiro: IBGE; 2015.

4. 4. Parahyba MI, Veras RP, Melzer D. Incapacidade funcional entre as mulheres idosas no Brasil. Rev Saúde Publica 2005;39(3):381-91.

5. Alves LC, Leite IC, Machado CJ. Conceituando e mensurando a incapacidade funcional da população idosa: uma revisão de literatura. Ciênc Saúde Coletiva 2009;13(4):1199-1207.

6. Organização Mundial da Saúde; Centro Colaborador da Organização Mundial da Saúde para a Família de Classificações Internacionais. CIF: Classificação Internacional de Funcionalidade, Incapacidade e Saúde. São Paulo: EDUSP; 2003. p.13-32.

7. Brasil. Portaria n 2.528 de 19 de outubro de 2006. Aprova a Política Nacional de Saúde da Pessoa Idosa. Diário Oficial da União 19 out 2006.

8. Del Duca GF, Silva MC, Hallal PC. Incapacidade funcional para atividades básicas e instrumentais da vida diária em idosos. Rev Saúde Publica 2009; 43(5):796-805.

9. Lebrão ML, Duarte YAO, organizadores. SABE Saúde, Bem-Estar e Envelhecimento: o projeto SABE no Município de São Paulo: uma abordagem inicial [Internet]. Brasília, DF: OPAS; 2003 [acesso em 13 mar 2013]. Disponível em: http://bvsms.saude.gov. br/bvs/publicacoes/envelhecimento_ativo.pdf

10. American Heart Association. Heart disease and stroke statistic - 2016 Update: a report from the American Heart Association. Circulation 2016;133:167-76.

11. Miller EL, Murray L, Richards L, Zorowitz RD, Bakas T, Clark P, et al. Comprehensive overview of nursing and interdisciplinary rehabilitation care of the stroke patient: a scientific statement from the American Heart Association. Stroke 2010;41:2402-44.

12. Rolim CLRC, Martins M. O uso da tomografia computadorizada nas internações por Acidente Vascular Cerebral no Sistema Único de Saúde no Brasil. Rev Bras Epidemiol 2012;15(1):179-87.
13. Rosa TE, Benicio MH, Latorre MR, Ramos LR. Fatores determinantes da capacidade funcional entre idosos. Rev Saúde Pública 2003;37(1):40-8.

14. Barbosa BR, Almeida JM, Barbosa MR, Barbosa LAR. Avaliação da capacidade funcional dos idosos e fatores associados a incapacidade. Ciênc Saúde Coletiva 2014;19(8):3317-25.

15. Organização Pan-Americana da Saúde. As redes de atenção a saúde. Brasília, DF: OPAS; 2011.

16. Vitória, ES. Secretaria de Saúde. Gerencia de Atenção a Saúde. Vitória: Prefeitura Municipal de Vitória; 2013.

17. Cruz SCS. Avaliação do processo de implantação da Estrategia de Saúde da Família: o caso de Resistência, Vitória/ES [dissertação]. Vitória,ES: Universidade Federal do Espírito Santo; 2007.

18. Pereira ABCN, Alvarenga H, Pereira JRS, Barbosa MTS. Prevalência de acidente vascular cerebral em idosos no Município de Vassouras, Rio de Janeiro, Brasil, através do rastreamento de dados do Programa Saúde da Família. Cad Saúde Pública 2009;25(9):1929-36.

19. Chandra RV, Leslie-Mazwi TM, Oh DC, Chaudhry ZA, Mehta BP, Rost NS, et al. Elderly patients are at higher risk for poor outcomes after intra-arterial therapy. Stroke 2012;43(9):2356-61.

20. Quinn TJ, Dawson J, Walters MR, Lees KR. Reliability of the Modified Rankin Scale: a Systematic Review. Stroke 2009;40(10):3393-5.

21. Hardie K, Hankey GJ, Jamrozik K, Broadhurst RJ, Anderson C. Ten-year risk of first recurrent stroke and disability after first-ever stroke in the Perth Community Stroke Study. Stroke 2004;35(3):731-5.

22. Bettger JP, Zhao X, Bushnell C, Zimmer L, Pan W, Willians LS, et al. The association between socioeconomic status and disability after stroke: Findings from the Adherence Evaluation After Ischemic Stroke longitudinal (AVAIL) registry. BMC Public Health 2014;14:281.

23. Schnitzler A, Woimant F, Tuppin P, De Peretti C. Prevalence of self reported stroke and disability in the french adult population: a transversal study. PLoS ONE 2014;9(12):115-375.

24. Bensenor IM, Goulart AC, Szwarcwald CL, Vieira MLFP, Malta DC, Lotufo PA. Prevalence of stroke and associated disability in Brazil: National Health Survey - 2013. Arq Neuropsiquiatr 2015;73(9):746-50. 
25. Carod-artal FJ, Trizotto DS, Coral LF, Moreira CM. Determinants of quality of life in Brazilian stroke survivors. J Neurol Sci 2009;284(1):63-8.

26. Khealani BA, Khan M, Tariq M, Malik A, Siddiqi AI, Awan S, et al. Ischemic Strokes in Pakistan: observations from the National Acute Ischemic Stroke Database. J Stroke Cerebrovasc Dis 2014;23(6):1640-7.

27. Kisoli A, Gray WK, Dotchin CL, Orega G, Dewhurst F, Paddick SM, et al. Levels of functional disability in elderly people in Tanzania with dementia, stroke and Parkinson's disease. Acta Neuropsychiatr 2015;27:206-12.

28. Carmo JF, Morelato RL, Pinto HP, Oliveira ERA. Disability after stroke: a systematic review. Fisioter Mov 2015;28(2):407-18.

29. Alves LC, Leite IC, Machado CJ. Fatores associados à incapacidade funcional dos idosos no Brasil: análise multinível. Rev Saúde Pública 2010;44(3):468-78.
30. Lien WC, Guo NW, Chang JH, Lin YC, Kuan TS. Relationship of perceived environmental barriers and disability in community-dwelling elderly in Taiwan: a population-based study. BMC Geriatr 2014;14:1-15

31. Zhang L, Yan T, You L, Li K. Barriers to activity and participation for stroke survivors in rural China. Arch Phys Med Rehabil 2015;96(7):1222-8.

32. Organização Mundial de Saúde. World report on ageing and health. Genebra: WHO; 2015.

33. Gall SL, Dewey HM, Sturm JW, Macdonell RA, Thrift AG. Handicap 5 years after stroke in the North East Melbourne Stroke Incidence Study. Cerebrovasc Dis 2009;27(2):123-30.

34. Park JH, Ovbiagele B. Relationship of functional disability after a recent stroke with recurrent stroke risk. Eur J neurol 2016;23(2):361-7. 